Journal of the Oceanographical Society of Japan

Vol. 23, No. 4, pp. 201 to 212, August 1967

\title{
東対馬水道の海況変動についで
}

南日俊夫** 藤木明光 ${ }^{* *}$

\section{Secular Variation of Hydrographic Conditions in the East Tsushima Strait}

\author{
Tosio NAN-NITI and Akimitsu FuJIKI
}

\begin{abstract}
The mean values of water temperatures and salinities in the East Tsushima Strait were computed from the monthly observations extending for about 40 years, and the periodicities of temperatures were estimated to be 2,7 and 8 years.

The heavy snow cover on the coast of the Japan Sea seems to have more relation to the low air temperature than the sea water temperature.
\end{abstract}

\section{1. まえがき}

福岡県福岡水産試験場は 1913 年から毎月 1 回 の東対馬水道の定線観測を続けてきている. 本報 告はそのうち 1952 年までの約 40 年にわたる資料 の解析を試みたものである。

\section{2. 月平均值}

海洋観測資料 ${ }^{1)}$ は㛜原〜玄界島間に 7 定点を選 び（Fig. 1) 毎月 1 回観測したものである.その 観測日時は一定してないが，毎月上旬に行なわれ たものが多く（Table 1)，その観測時間も玄海島 沖 (St. 1) は午前 8 時頃, 厳原沖 (St. 7) 方午後 5 時頃となっている.

今観測日時の不同を問わず, 各月平均值を求め ると Fig. 2 を得る.これから 3 月が最低, 8 月が 最高の温度を示しているのがみられる。 また最大 の時間的変化は, 気温は 1 か月で $4^{\circ} \mathrm{C}$, 表面水温 は 1 か月で $3^{\circ} \mathrm{C}, 50 \mathrm{~m}$ 層水温は 1 か月で $1.5^{\circ} \mathrm{C}$ も 異なってくる. それ故たとえば観測日の 5 日のず れは気温で $0.7^{\circ} \mathrm{C}$, 表面水温で $0.5^{\circ} \mathrm{C}$ 程度の補正 を要することもあり得ると考えられるが，実際の

* 1967 年 5 月 31 日受理 1967 年 4 月 9 日 日本海洋学会春季大会にて講演 ** 気象研究所 Meteorological Research Institute
その日の時間変化率はどうであったか知るすべも ないから日時の補正は行なわない。

一方これらの月別標準偏差の最大值は, 気温 $3.0^{\circ} \mathrm{C}$ (1 月), 表面水温 $2.1^{\circ} \mathrm{C}(9$ 月), $25 \mathrm{~m}$ 層 水温 $2.0^{\circ} \mathrm{C}$ (9 月) である (Table 2).

Table 1 からわかるように観測日の不同が多く， 5 日程度のずれは相当な数になり，もしこの観測 日時が一定して行なわれてきたのであったならば 標準偏差も今少し小さい值になったであろう。

年平均值の標準偏差は Table 2 に示すように気 温 $0.7^{\circ} \mathrm{C}$, 表面水温 $0.4^{\circ} \mathrm{C}, 25 \mathrm{~m}$ 層水温 $0.3^{\circ} \mathrm{C}$, である。

以上述べたように観測日時不同の資料を算術平 均したものを Fig. 1 に示す. 12〜3 月はよく上 下混合した冬型，6〜10 月は成層をなす夏型であ る.

これらの図より対馬暖流は Sts. 5，6 あたりに 流軸があるように考えられる. また 6 月から急激 に塩分濃度が減じ，8 月には極小になる。これは 陸水の影響, すなわち黄海冷水の流入と考えられ る.

Fig. 3 に示すょうに $2,3,4$ 月は上下均一の $\sigma_{t}=25.9$ の水塊を示しているが, 次第に水温が上 昇すると共に塩分は減じ，6，7，8，9，10月は底 層 $100 \mathrm{~m}$ 層はいずれも塩分 $34.30 \%$ 程度 $\left(\sigma_{t}=24.9\right.$ 


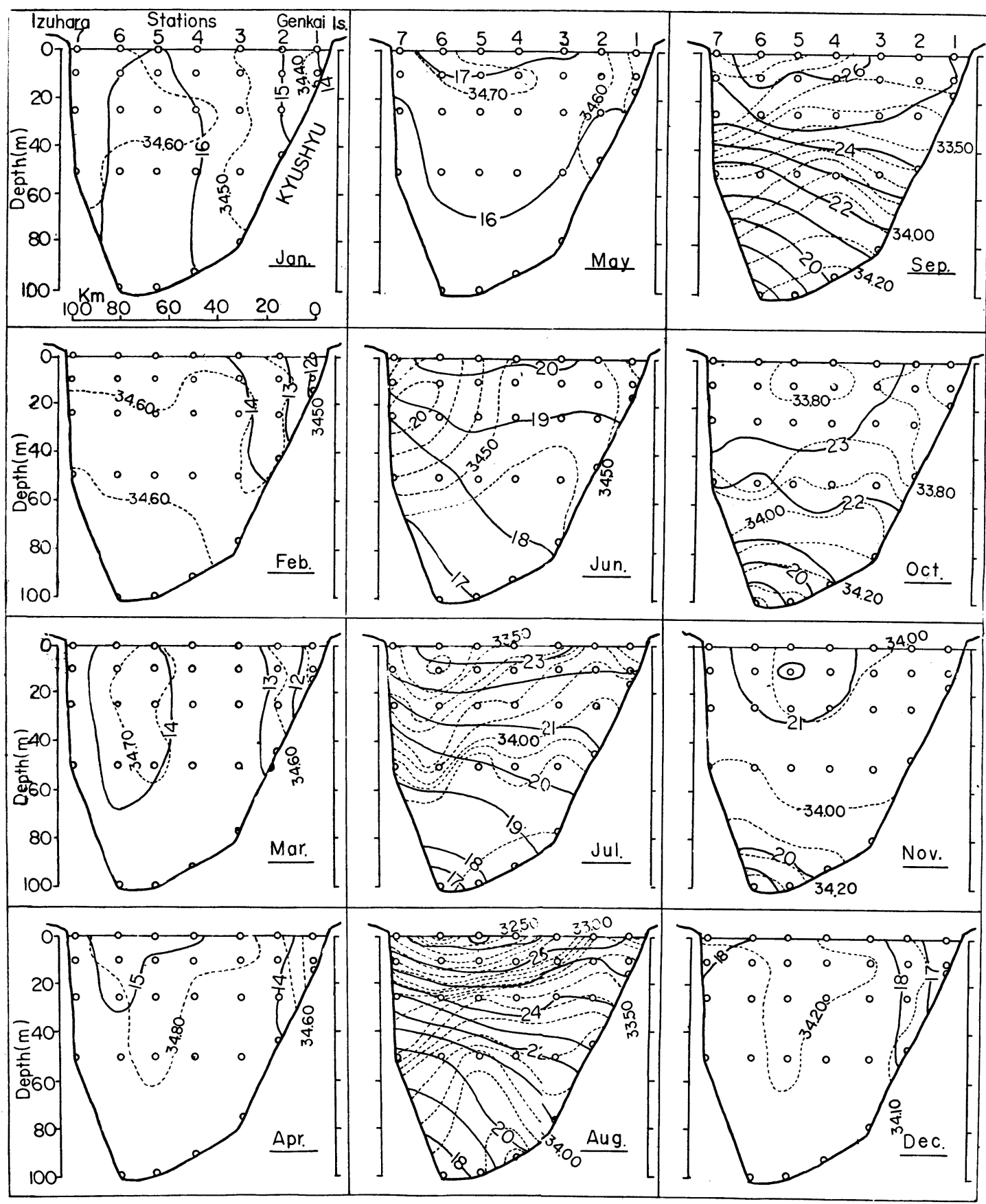

Fig. 1. Monthly vertical sections of temperature in degrees centigrade $\left(\mathrm{T}^{\circ} \mathrm{C}\right.$ thin line) salinity in perts per mille (S\% dotted line) in the Tsushima Strait. 
Table 1. Frequency distributions of date of observations.

\begin{tabular}{|c|c|c|c|c|c|c|c|c|c|c|c|c|c|c|c|c|c|}
\hline Month & Jan & Feb & Mar & Apr & May & $\mathrm{Ju}$ & in & $\mathrm{Jul}$ & & Aug & $\mathrm{Se}$ & ep & Oc & $c t$ & Nov & Dec & Total \\
\hline Date & $\mathrm{N} \%$ & $\mathrm{~N} \%$ & $\mathrm{~N} \%$ & $\mathrm{~N} \%$ & $\mathrm{~N} \%$ & $\mathrm{~N}$ & $\%$ & $\mathrm{~N}$ & $\%$ & $\mathrm{~N} \%$ & & $\%$ & $\mathrm{~N}$ & $\%$ & $\mathrm{~N} \%$ & $\mathrm{~N} \%$ & $\mathrm{~N} \%$ \\
\hline 1 & $-\quad-$ & 13 & 26 & 27 & 26 & 2 & 6 & - & - & 517 & 3 & 9 & 1 & 3 & 13 & 515 & 246.3 \\
\hline 2 & $-\quad-$ & 413 & 413 & 27 & 516 & - & - & 41 & 13 & 27 & 2 & 6 & 41 & 11 & 27 & 412 & 338.6 \\
\hline 3 & $-\quad-$ & 13 & 26 & $-\quad-$ & 26 & 1 & 3 & 61 & 19 & 310 & & 15 & 51 & 15 & 413 & 26 & 318.1 \\
\hline 4 & $-\quad-$ & 13 & 310 & 13 & 516 & 2 & 6 & 1 & 3 & 27 & & 21 & 2 & 6 & 620 & 515 & 359.2 \\
\hline 5 & 27 & 413 & 26 & 13 & 13 & 10 & 31 & - & - & 27 & - & - & & 15 & 27 & - & 297.6 \\
\hline 6 & $-\quad-$ & 413 & 13 & 27 & 26 & 3 & 9 & 3 & 9 & 27 & 2 & 6 & 2 & 6 & 13 & 39 & 256.5 \\
\hline 7 & 517 & - & 413 & - & 39 & 2 & 6 & 2 & 6 & 310 & 2 & 6 & 3 & 9 & 310 & 13 & 287.3 \\
\hline 8 & $-\quad-$ & 39 & 13 & 310 & 13 & 2 & 6 & 3 & 9 & 13 & 2 & 6 & 1 & 3 & 13 & 39 & 215.5 \\
\hline 9 & 13 & $-\quad-$ & 516 & $-\quad-$ & 413 & - & - & 3 & 9 & 27 & 1 & 3 & 2 & 6 & $-\quad-$ & $-\quad-$ & 184.7 \\
\hline 10 & 310 & $-\quad-$ & $-\quad-$ & 13 & 26 & 3 & 9 & 1 & 3 & 13 & 1 & 6 & 1 & 3 & 13 & 26 & 174.5 \\
\hline 11 & 413 & $-\quad-$ & 13 & $-\quad-$ & $-\quad-$ & - & - & 2 & 6 & 13 & - & - & 2 & 6 & 13 & 13 & 123.1 \\
\hline 12 & 310 & 26 & $-\quad-$ & 27 & 13 & - & - & - & - & - & - & - & 2 & 6 & 27 & 13 & 133.4 \\
\hline 13 & $-\quad-$ & 413 & 13 & 27 & $-\quad-$ & 1 & 3 & - & - & $-\quad-$ & 1 & 3 & - & - & 310 & 13 & 133.4 \\
\hline 14 & 310 & 13 & 13 & 27 & $-\quad-$ & - & - & 1 & 3 & 13 & 1 & 3 & - & - & $-\quad-$ & 13 & 112.9 \\
\hline 15 & 27 & $-\quad-$ & 13 & 13 & $-\quad-$ & 1 & 3 & - & - & $-\quad-$ & - & - & 1 & 3 & $-\quad-$ & $-\quad-$ & 61.6 \\
\hline 16 & 310 & 13 & $-\quad-$ & 310 & 13 & - & - & - & - & $-\quad-$ & - & - & - & - & $-\quad-$ & 13 & 92.4 \\
\hline 17 & $-\quad-$ & 13 & 13 & 27 & $-\quad-$ & 1 & 3 & 1 & 3 & 13 & - & - & - & - & -- & $-\quad-$ & 71.8 \\
\hline 18 & $-\quad-$ & $-\quad-$ & $-\quad-$ & $-\quad-$ & $-\quad-$ & - & - & 1 & 3 & $-\quad-$ & - & - & 1 & 3 & $-\quad-$ & 13 & 30.8 \\
\hline 19 & 13 & 13 & $-\quad-$ & $-\quad-$ & $-\quad-$ & - & - & - & - & 13 & 1 & 3 & 1 & 3 & 13 & $-\quad-$ & 61.6 \\
\hline 20 & $-\quad-$ & 13 & $-\quad-$ & 13 & $-\quad-$ & - & - & - & - & $-\quad-$ & - & - & - & - & - & $-\quad-$ & 20.5 \\
\hline 21 & 13 & $-\quad-$ & $-\quad-$ & $-\quad-$ & $-\quad-$ & - & - & - & - & $-\quad-$ & - & - & - & - & $-\quad-$ & 13 & 20.5 \\
\hline 22 & $-\quad-$ & $-\quad-$ & $-\quad-$ & $-\quad-$ & $-\quad-$ & 1 & 3 & - & - & $-\quad-$ & - & - & - & - & $-\quad-$ & $-\quad-$ & 10.3 \\
\hline 23 & 13 & $-\quad-$ & $-\quad-$ & $-\quad-$ & 13 & - & - & - & - & $-\quad-$ & - & - & - & - & $-\quad-$ & $-\quad-$ & 20.5 \\
\hline 24 & $-\quad-$ & $-\quad-$ & 13 & $-\quad-$ & $-\quad-$ & 1 & 3 & - & - & $-\quad-$ & - & - & - & - & $-\quad-$ & $-\quad-$ & 20.5 \\
\hline 25 & $-\quad-$ & $-\quad-$ & $-\quad-$ & 27 & $-\quad-$ & - & - & 1 & 3 & $-\quad-$ & 1 & 3 & - & - & $-\quad-$ & $-\quad-$ & 41.0 \\
\hline 26 & $-\quad-$ & 13 & $-\quad-$ & $-\quad-$ & $-\quad-$ & - & - & - & - & $-\quad-$ & - & - & - & - & $-\quad-$ & $-\quad-$ & 10.3 \\
\hline 27 & $-\quad-$ & $-\quad-$ & $-\quad-$ & $-\quad-$ & $-\quad-$ & - & - & - & - & $-\quad-$ & - & - & - & - & $-\quad-$ & $-\quad-$ & 00.0 \\
\hline 28 & $-\quad-$ & $-\quad-$ & $-\quad-$ & $-\quad-$ & $-\quad-$ & - & - & - & - & $-\quad-$ & 1 & 3 & - & - & $-\quad-$ & $-\quad-$ & 10.3 \\
\hline 29 & $-\quad-$ & $-\quad-$ & $-\quad-$ & $-\quad-$ & $-\quad-$ & - & - & - & - & $-\quad-$ & - & - & - & - & $-\quad-$ & $-\quad-$ & 00.0 \\
\hline 30 & $-\quad-$ & $-\quad-$ & $-\quad-$ & $-\quad-$ & $-\quad-$ & - & - & - & - & $-\quad-$ & - & - & - & - & $-\quad-$ & $-\quad-$ & 00.0 \\
\hline 31 & $-\quad-$ & $-\quad-$ & $-\quad-$ & $-\quad-$ & $-\quad-$ & - & - & - & - & $-\quad-$ & - & - & - & - & $-\quad-$ & $-\quad-$ & 00.0 \\
\hline $\begin{array}{l}\text { The date } \\
\text { unknown }\end{array}$ & 13 & 26 & 13 & 310 & 26 & 2 & 6 & 3 & 9 & 310 & 3 & 9 & 2 & 6 & 27 & 26 & 266.8 \\
\hline Total & 30 & 32 & 31 & 30 & 32 & 32 & & 32 & & 30 & 34 & & 35 & & 30 & 34 & 382 \\
\hline
\end{tabular}


Table 2. Mean monthly water and air temperature $\left(\mathrm{T}^{\circ} \mathrm{C}\right)$, and their standard deviations $(\sigma)$ during the period 1913-1952.

\begin{tabular}{|c|c|c|c|c|c|c|c|c|c|c|c|c|c|}
\hline Month & Jan & Feb & Mar & Apr & May & Jun & Jul & Aug & Sep & Oct & Nov & Dec & $\begin{array}{c}\text { Annual } \\
\text { mean }\end{array}$ \\
\hline St. $1 T_{0}$ & 13.1 & 11.6 & 11.6 & 13.5 & 16.3 & 19.8 & 22.8 & 26.0 & 24.9 & 22.6 & 19.3 & 16.1 & \\
\hline$\sigma_{0}$ & 0.96 & 1.05 & 1.13 & 2.66 & 1.03 & 1.00 & 1.43 & 1.48 & 2.06 & 0.98 & 0.80 & 1.21 & 0.41 \\
\hline$T_{25}$ & 13.2 & 11.7 & 11.4 & 13.4 & 16.1 & 19.2 & 21.7 & 25.0 & 24.8 & 22.8 & 19.5 & 16.3 & \\
\hline$\sigma_{25}$ & 0.86 & 0.91 & 0.76 & 0.73 & 0.90 & 0.87 & 0.96 & 1.04 & 1.98 & 1.27 & 0.55 & 2.10 & 0.33 \\
\hline$T_{a}$ & 8.1 & 7.3 & 9.0 & 13.1 & 17.6 & 20.9 & 25.0 & 27.9 & 25.4 & 19.8 & 15.3 & 10.3 & \\
\hline$\sigma_{a}$ & 2.47 & 2.62 & 2.87 & 2.01 & 2.40 & 2.42 & 2.44 & 1.41 & 2.05 & 1.47 & 2.25 & 2.77 & 0.66 \\
\hline St. $4 T_{0}$ & 15.7 & 14.1 & 13.9 & 15.1 & 17.2 & 20.0 & 23.5 & 27.2 & 26.3 & 23.7 & 21.1 & 18.2 & \\
\hline$\sigma_{0}$ & 1.11 & 0.93 & 0.97 & 1.04 & 1.14 & 0.93 & 1.45 & 1.50 & 1.82 & 0.96 & 0.95 & 1.39 & 0.35 \\
\hline$T_{25}$ & 16.0 & 14.5 & 13.9 & 14.7 & 16.6 & 19.1 & 21.6 & 24.8 & 25.3 & 23.3 & 21.0 & 18.6 & \\
\hline$\sigma_{25}$ & 0.72 & 0.86 & 0.78 & 0.74 & 0.99 & 0.76 & 1.24 & 1.50 & 1.96 & 1.10 & 0.87 & 0.82 & 0.31 \\
\hline$T_{a}$ & 9.1 & 8.2 & 10.9 & 15.4 & 19.1 & 22.3 & 25.5 & 29.1 & 26.3 & 22.6 & 17.9 & 13.1 & \\
\hline$\sigma_{a}$ & 2.86 & 3.43 & 2.11 & 2.39 & 2.26 & 1.60 & 2.20 & 2.30 & 2.08 & 2.29 & 2.69 & 2.50 & 0.70 \\
\hline St. $6 T_{0}$ & 15.7 & 14.3 & 14.2 & 15.3 & 17.5 & 20.5 & 23.3 & 27.6 & 26.4 & 23.7 & 21.2 & 18.0 & \\
\hline$\sigma_{0}$ & 1.03 & 0.84 & 0.85 & 0.87 & 1.27 & 1.45 & 1.31 & 1.71 & 1.75 & 0.97 & 1.07 & 1.33 & 0.36 \\
\hline$T_{25}$ & 16.1 & 14.7 & 14.3 & 15.1 & 16.6 & 18.9 & 21.6 & 24.0 & 25.2 & 23.3 & 21.0 & 18.6 & \\
\hline$\sigma_{25}$ & 0.75 & 0.89 & 0.56 & 0.68 & 0.81 & 1.16 & 1.17 & 2.62 & 2.15 & 0.87 & 1.27 & 0.76 & 0.37 \\
\hline$T_{a}$ & 9.0 & 8.2 & 10.8 & 14.8 & 18.9 & 21.8 & 25.0 & 28.0 & 26.0 & 22.2 & 17.5 & 12.6 & \\
\hline$\sigma_{a}$ & 3.04 & 3.52 & 2.65 & 2.02 & 2.12 & 1.56 & 1.97 & 2.87 & 1.94 & 2.62 & 2.72 & 2.90 & 0.74 \\
\hline
\end{tabular}

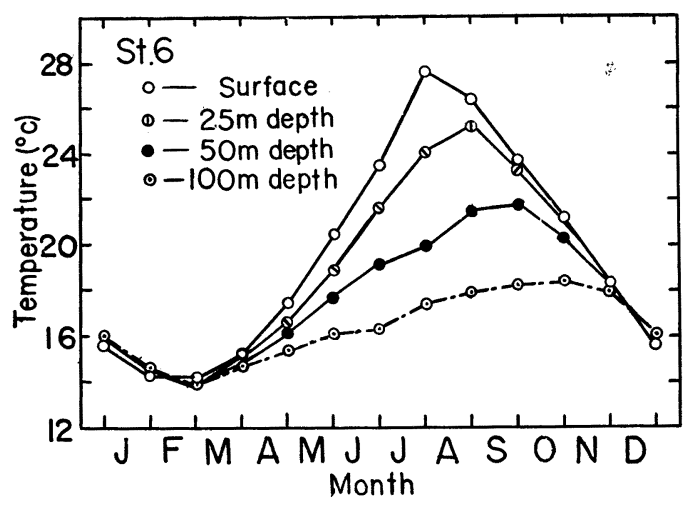

Fig. 2. Annual variation of mean water temperature at St. 6 .

程度）であるが上層の塩分は各月大いに異なる。

いま水平及び鉛直方向の拡散を次式で表現され るとする

$$
\begin{aligned}
& \frac{\partial S}{\partial t}=v \cdot \frac{\partial S}{\partial y}+K_{h} \frac{\partial^{2} S}{\partial y^{2}} \\
& \frac{\partial T}{\partial t}=K_{z} \frac{\partial^{2} T}{\partial z^{2}}
\end{aligned}
$$

ここに $x$ は流れの方向, $y$ はこれに直角, $z$ は鉛 直下方にとり, $v$ は $y$ 方向の流速, $S$ は塩分, $T$
は水温， $K_{h}, K_{z}$ はそれぞれ水平及び鉛直拡散係 数とする.

そこで (1) 式について $v \approx 1 \mathrm{~cm} \cdot \mathrm{sec}^{-1}, \frac{\partial S}{\partial t} \approx$ $3 \times 10^{-7} \% \cdot \cdot \mathrm{sec}^{-1}$ (Fig. 3 より), $\frac{\partial S}{\partial y} \approx 0.8 \times 10^{-7}$ $\%_{0} \cdot \mathrm{cm}^{-1}, \frac{\partial^{2} S}{\partial y^{2}} \approx 4 \times 10^{-14} \%_{0} \cdot \mathrm{cm}^{-2}$ (Fig. 2 より) 等を代入すると， $K_{h} \approx 5 \times 10^{6} \mathrm{~cm}^{2} \cdot \mathrm{sec}^{-1}$ となる.

次に（2）式について表面水温を

$T=a_{1} \cos \left(\sigma t-\alpha_{1}\right)+a_{2} \cos \left(2 \sigma t-\alpha_{2}\right) \quad$ とおくと 1 年及び半年周期の振幅, 位相差, 拡散係数 ${ }^{2}$ は それぞれ Table 3 の如くなる.

以上の如く $K_{h} \approx 5 \times 10^{6} \mathrm{~cm}^{2} \cdot \mathrm{sec}^{-1}$ (運動量拡散 係数), $K_{z} \approx 1 \mathrm{~cm}^{2} \cdot \mathrm{sec}^{-1}$ (熱拡散係数) はその現象 のスケールから言って普通求められている值であ り，また水平拡散現象のうずの寿命時間は 10 日 程度と考えられる ${ }^{3}$.

透明度については観測值は大変変動が大きい。

Sts. 5,6 は透明度がよく 7 9 月で $18 \mathrm{~m}, 3 \sim 5$ 月で $12 \mathrm{~m}$ 程度, St. 1 では 8 月が $12.9 \mathrm{~m}$, その 他の月は $9 \mathrm{~m}$ 程度である.

\section{3. 気温・水温の変動}

Sts. 1，4，6における気温, 水温の月偏差図を 


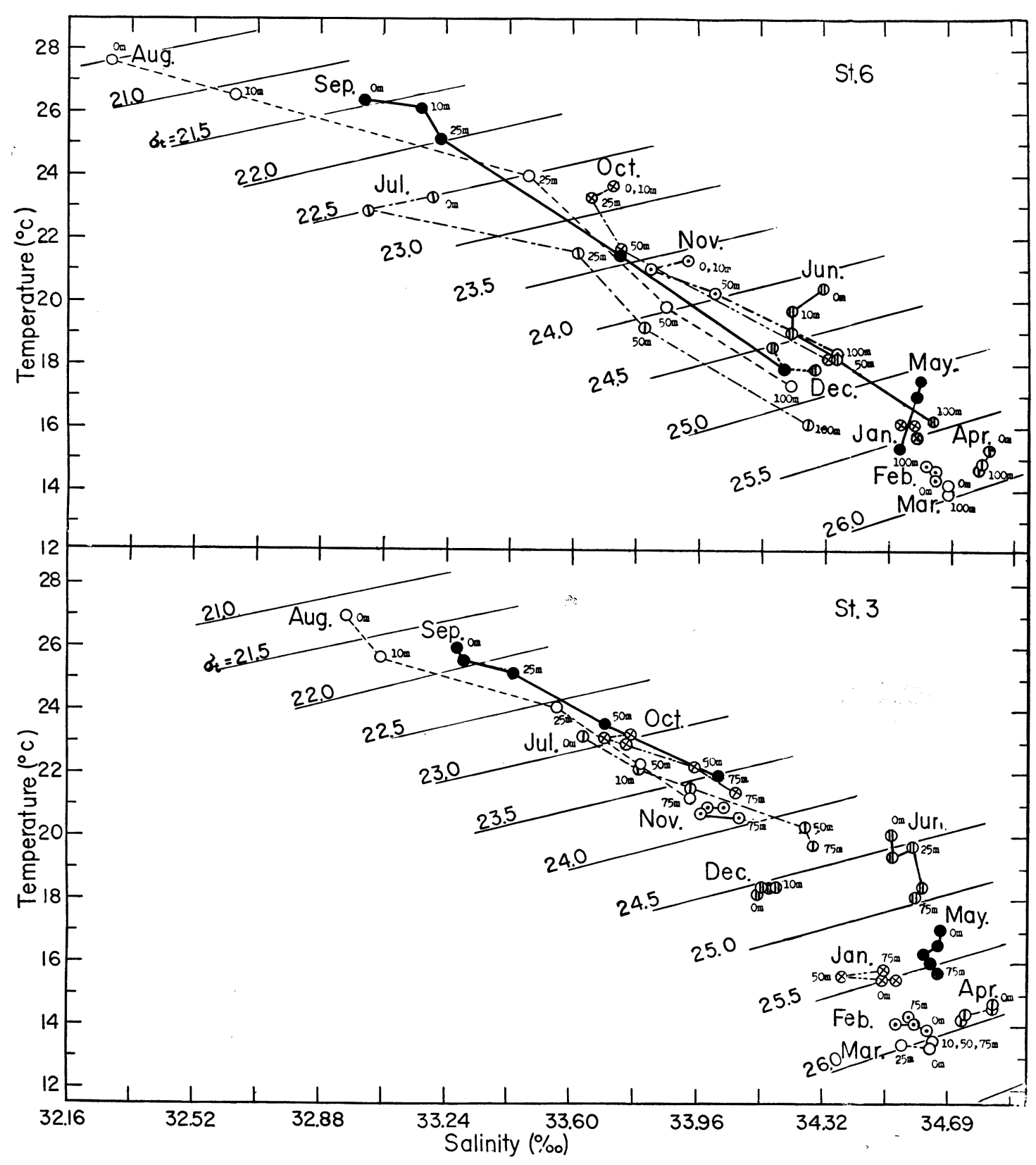

Fig. 3. $T-S$ diagram of Sts. 3 and 6 .

Table 3. Harmonic constants of the annual and semi-annual variations and eddy diffusion coefficients of water temperature.

\begin{tabular}{|c|c|c|c|c|c|c|}
\hline \multirow{2}{*}{ Depth (m) } & \multicolumn{3}{|c|}{ Annual variation } & \multicolumn{3}{|c|}{ Semi-annual variation } \\
\hline & $a\left({ }^{\circ} \mathrm{c}\right)$ & $\alpha\left(^{\circ}\right)$ & $K z_{1} \cdot \mathrm{cm}^{2} \cdot \mathrm{sec}^{-1}$ & $a\left({ }^{\circ} \mathrm{c}\right)$ & $\alpha\left({ }^{\circ}\right)$ & $K z_{2} \cdot \mathrm{cm}^{2} \cdot \mathrm{sec}^{-1}$ \\
\hline 0 & 6.3 & 227 & & 0.7 & 75 & \\
\hline 50 & 3.8 & 295 & 10 & 0.4 & 134 & 10 \\
\hline 100 & 2.0 & 281 & 4 & 0.1 & 169 & 3 \\
\hline
\end{tabular}




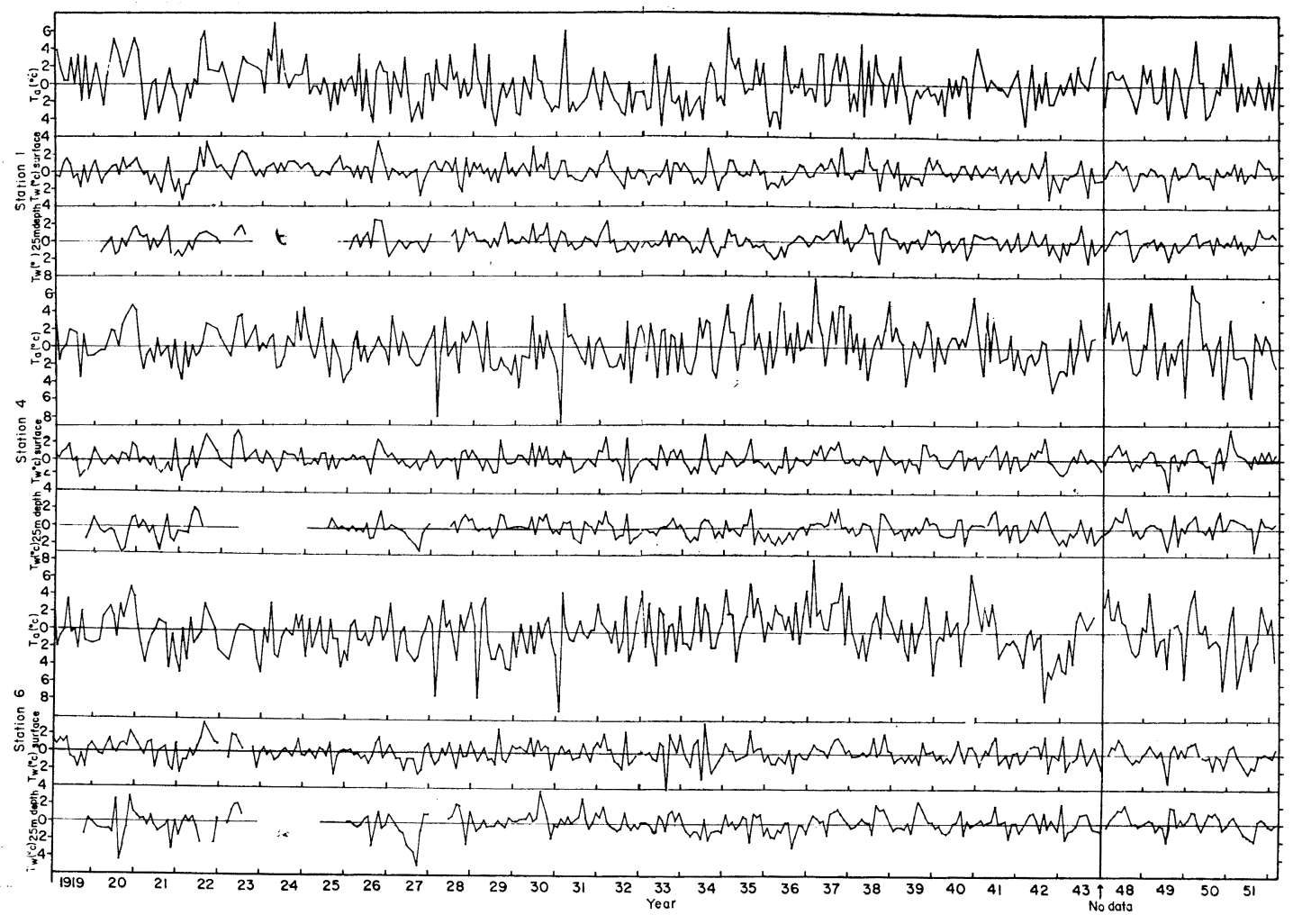

Fig. 4. Monthly anomalies of air and water temperature at Sts. 1, 4 and 6.

Fig. 4 に示す.これらお互いの間に割とよい平行 した変動がみられるのは当然である. その偏差の 最大值は気温で 1 か月で $6^{\circ} \mathrm{C}$, 時には $14^{\circ} \mathrm{C} に も$ 達する変動を示すこともあるが，打就よそ $4^{\circ} \mathrm{C}$ の 幅をもって変動し, 水温は最大 $4^{\circ} \mathrm{C} /$ 月, 打打占 そ $2^{\circ} \mathrm{C}$ の幅をもって変動する.

これらの水温の偏差值を MERIAC-I-F ${ }^{4)}$ によ って周期分析し, エネルギースペクトルを求める と, たとえば Fig. 5 が得られるが, 有意な周期は みられない.すなわち, 1 年以下の短周期につい ては有意水準が低く，また 2 年以上の長周期につ いては資料が短期間のため, 分析器の分解能が低 下して, 確かな周期の存在を指摘するるとは困難 である・

福岡 ${ }^{5)}$ が厳原の沿岸水温の変動調査において指 摘した 6 か月および 1 年の卓越周期の存在は, 資 料整理の過程と有意性の判別において誤りがある と思われる.すなわち, Fig. 5 の右肩に示すよう
に $a$ が $b$ を越えるのでなければ有意の周期性を認 め難い.

次に St. 6 の水温月偏差量について自己相関係 数を求めた $(\mathrm{Fig}, 6)$. ただし，この計算において は連続した資料が必要であるが，資料のない月に ついてはそれぞれの月平均值を用いた。これによ ると, 有意水準 (5\%) を超える值として, 正の 係数で $20 ， 25 ， 27 ， 41$ （49）只，負の係数で $12 ， 15 ， 35 ， 37 （ 48)$ か月がみられる. ただし （）は解析期間 180 月の $1 / 4$ を越えるため有意 性に疑問があることを示す．コレログラムの周期 性から $20 ， 25 ， 27$ か月，すなわち 2 年前後の周 期の存在は確かなようで, その振幅も他の周期の ものより大きいものと思われる.

次に長周期変動をみるため, 水温の年平均值を Fig. 7 に示す. St. 1 及び St. 4 では 7 年と 9 年, St. 6 では 9 年の周期が卓越している.

St. 6 について, $100 \mathrm{~m}$ 層までみると, いずれの 


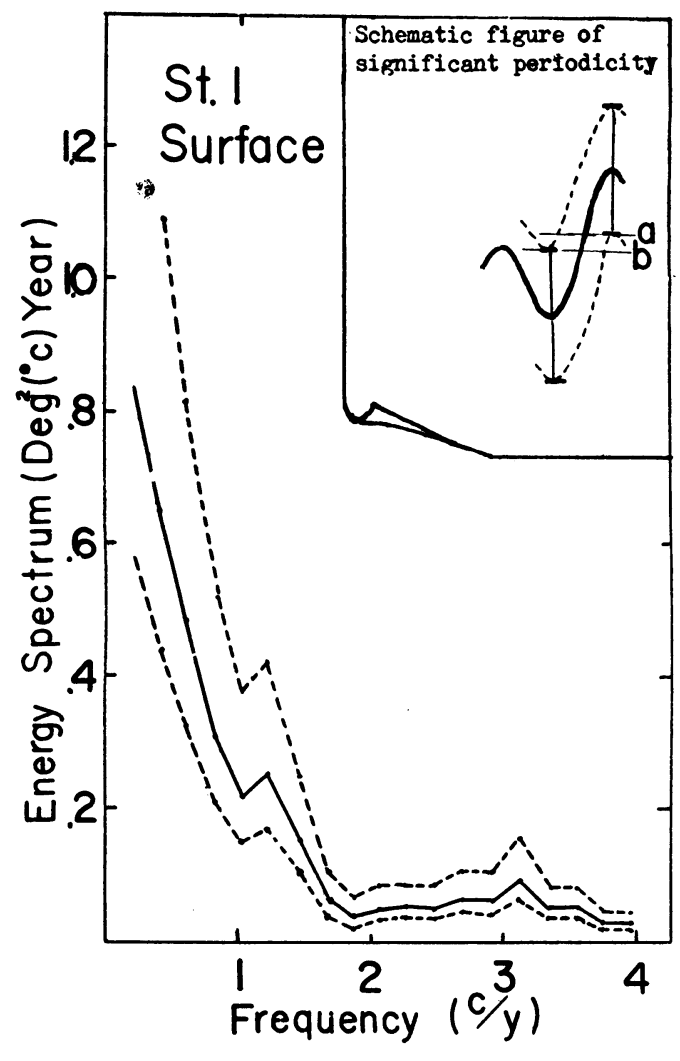

Fig. 5. Energy spectrum of surface water temperature at St. 1.

層にも 9 年の周期があり, その振幅は深層の方が 大きい。

また，この表面水温の長周期変動を季節別にみ
ると, Fig. 8 にみるように, 夏季 (7〜9 月の平均 值）は 8 年の周期が卓越し, 振幅は一番大きい. 冬季 (12 2 月の平均值) は 5 年及び更に長い周 期がみえるが，その振幅は小さい. 春季（3～5 月 の平均值) は 9 年, 秋季 $(10 \sim 11$ 月の平均值) に は 2 年と $14 \sim 16$ 年位の長周期があるようである.

これらの資料のコレログラムを求めてみると, Fig. 9 (a) になる. St. 6 では $50 \mathrm{~m}$ 層の 7 年, $100 \mathrm{~m}$ 層の 4,5 年 (負の係数) 等は有意である が, 表層の $4,7,9$ 年, $50 \mathrm{~m}$ 層の 2,9 年, 100 $\mathrm{m}$ 層の 6,9 年等は有意水準 $(5 \%)$ に達せずこ れらの周期の存在は確かでない.したがって 50 $\mathrm{m}$ 層からの 7 年の周期のみが確からしい.

また季節別では (Fig. 9 (b)), 夏季の 8 年, 秋 季の 2,6 年に負の係数が有意であるが， 4,12 年 等の周期は認められない.

また，気温については厳原測候所の月平均気温 について，自己相関係数を求めた. それによると 3, 7, 9 年の周期がみられる (Fig. 10).

以上をまとめると Table 4 のようになり，有意 な周期として, 水温では 2 年前後, 7,8 年, 気温 では $3,7,9$ 年と考えられる. しかし現今までの 水温の連続観測は 40 年程度であるので, 7,8 年 の周期を確認するには後 40 年程の観測を 続ける 必要があろう。

日高・鈴木 ${ }^{6}$ (は対馬暖流の流速に 7 年の周期を 認め, FUKUOKA ${ }^{7}$ は禄剛埼（能登半島）の水温に ついて $2,9,11,15$ 年の周期を認めている. そ

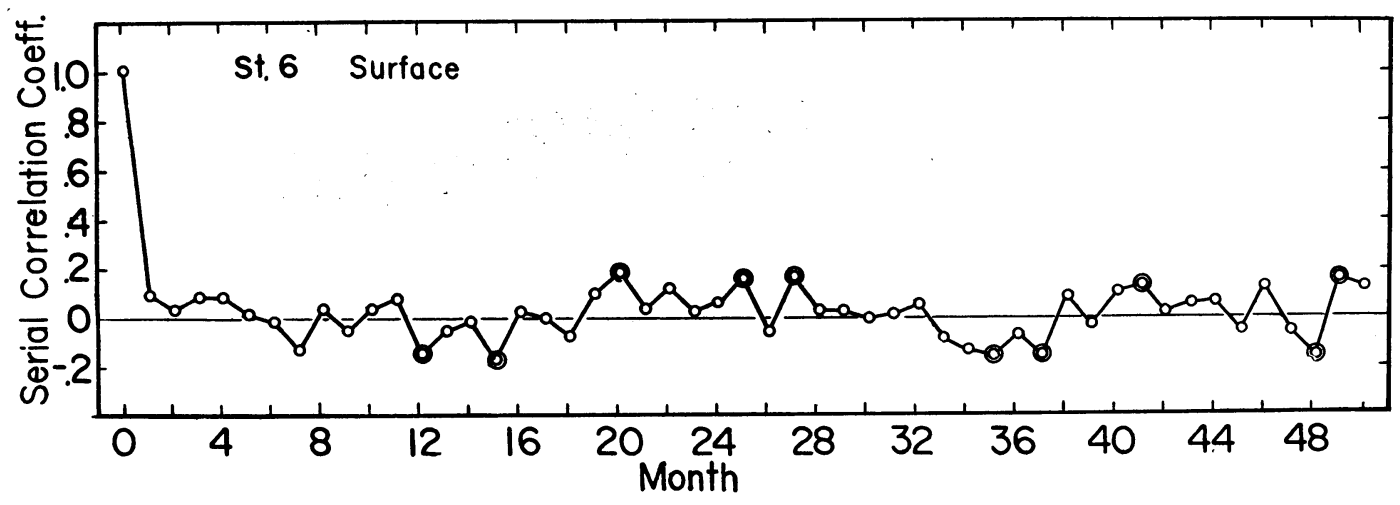

Fig. 6. Correlogram of surface water temperature at St. 6. Double circle shows the significant value at the $5 \%$ level. 
Table 4. Periods of air and water temperatures at Sts. 1, 4 and 6.

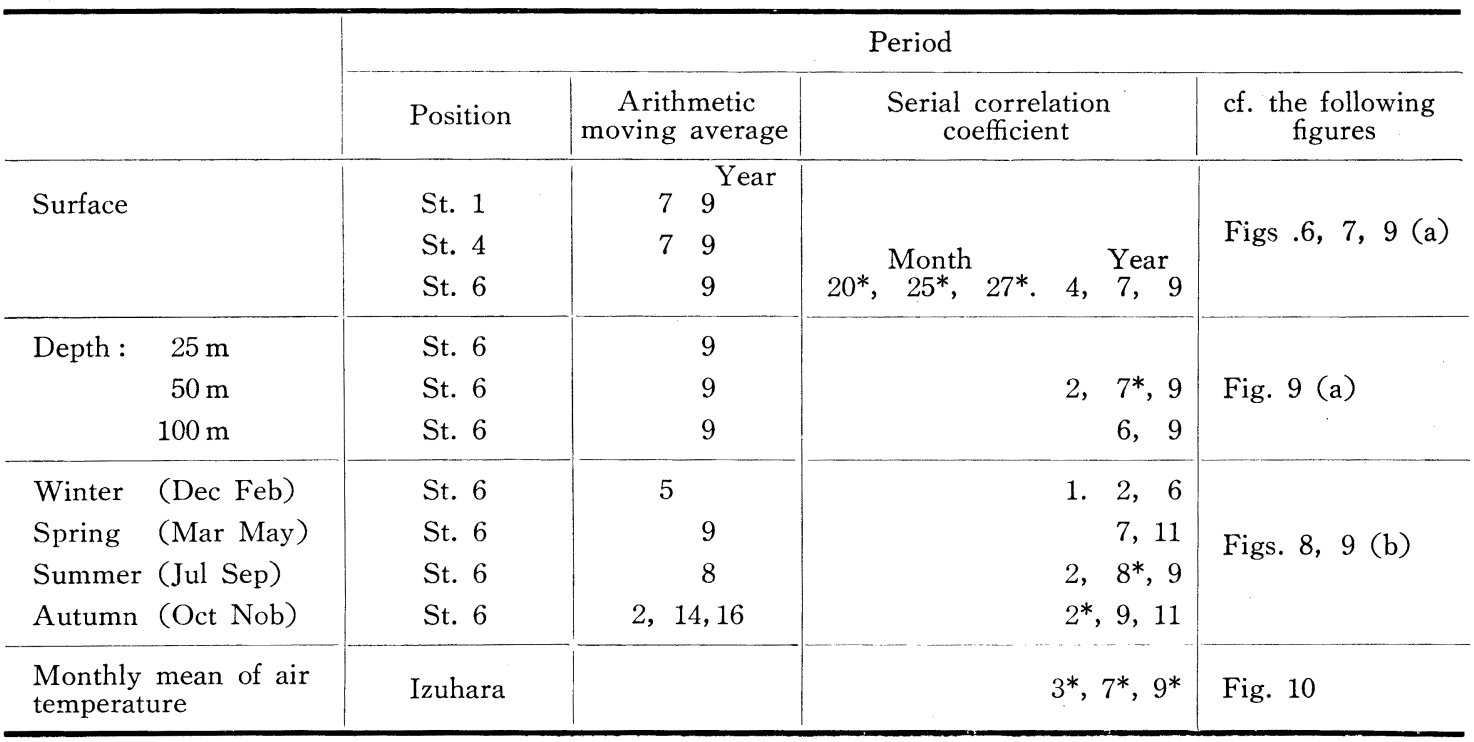

*: Significant at the $5 \%$ level

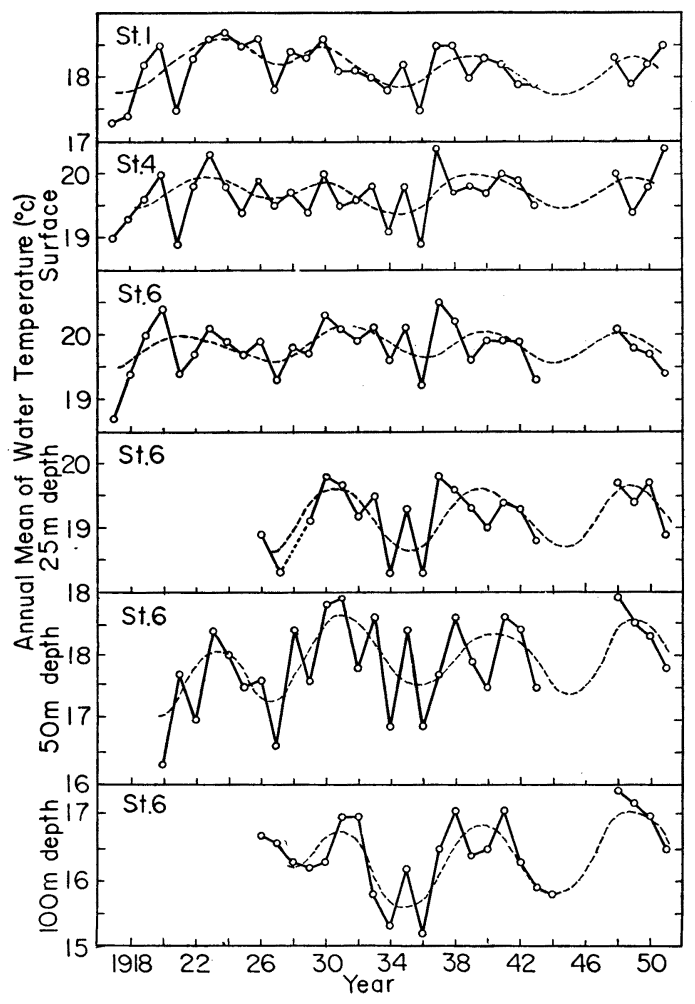

Fig. 7. Variations of annual mean of water temperature at Sts. 1, 4 and 6.

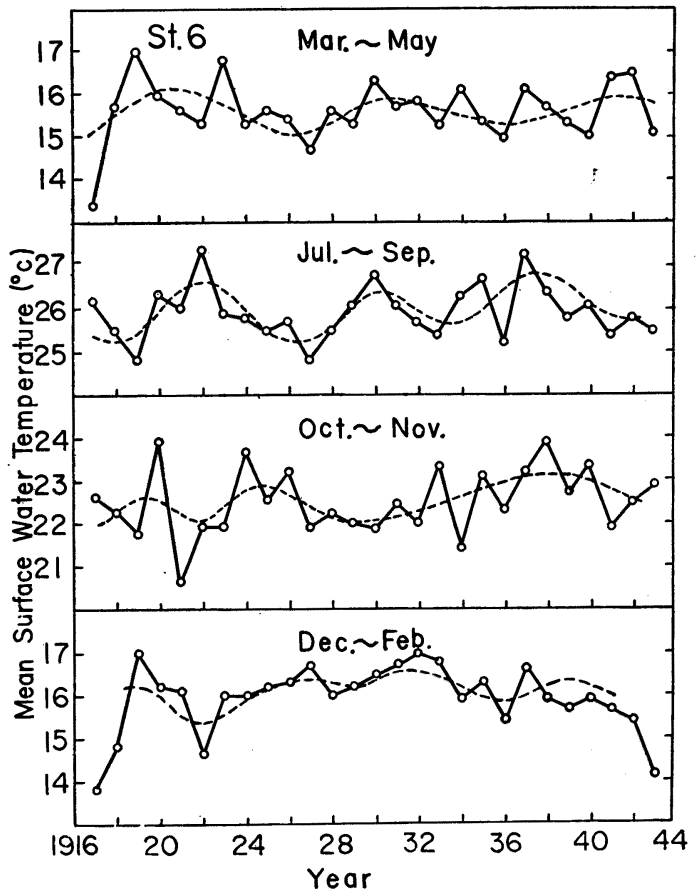

Fig. 8. Variations of mean surface water temperature in four seasons at St. 6. 


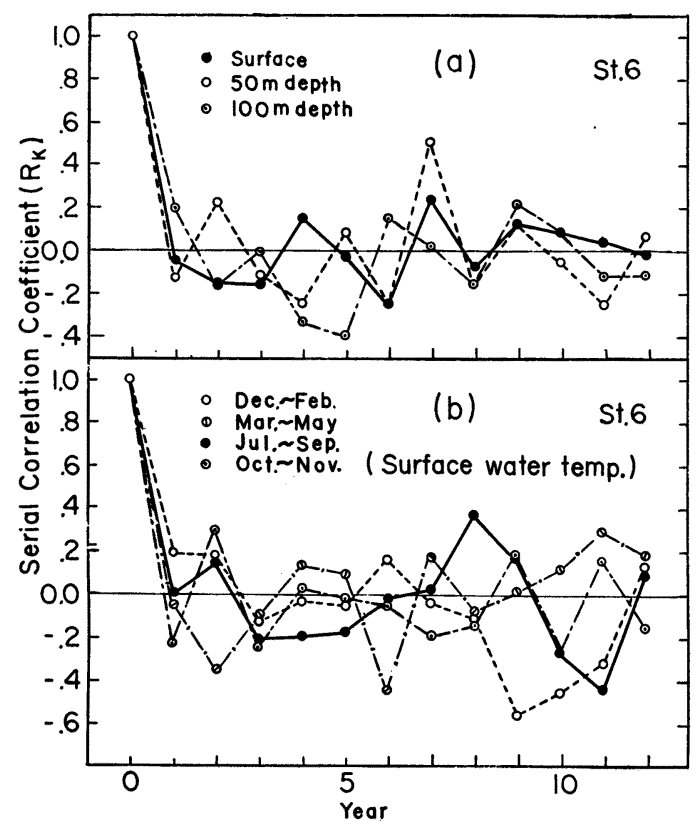

Fig. 9. Correlogram of water temperature at St. 6 . (a) in each layer, (b) in four seasons.

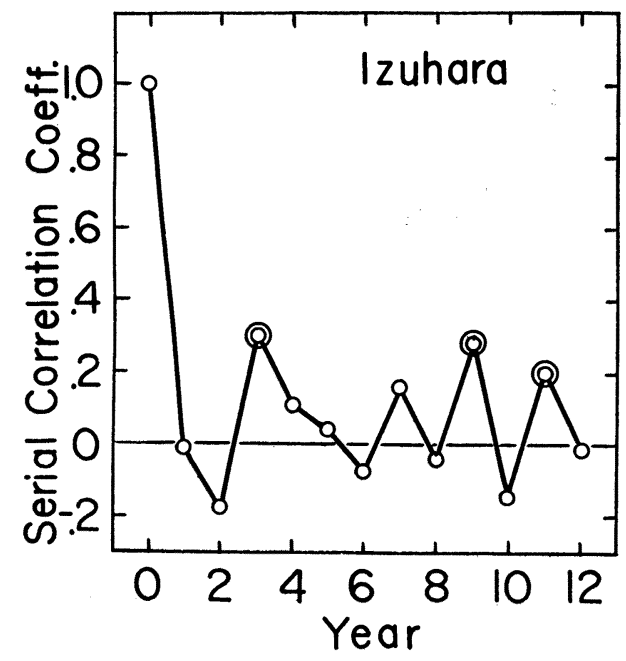

Fig. 10. Correlogram of air temperature at Izuhara.

の他黒潮について 4.5 年 ${ }^{8)}$ や 9 年 ${ }^{9)}$ の周期等著明 であるが，これらのことについては福岡 ${ }^{10)}$ の総説 がある・

\section{4. 気温 - 水温 降雪量との関連}

表面水温とその上層の気温との相関係数を求め
た. 1 4 月と 10〜12 月は 0.5 またはそれ以下, 5 9 月は $0.50 \sim 0.65,7$ 月が最も大きく 0.73 で ある. 気温と $25 \mathrm{~m}$ 層水温との相関係数はいずれ も 0.5 , 多くは 0.3 以下である. また表面水温と 雲量との相関係数は \pm 0.16 程度である.

次に北陸地方の降雪は日本海からの水蒸気と熱 の供給によるから,これと水温, 気温との関連を 調べた. Fig. 11 は福井, 伏木, 柏崎における里 雪の月最深積雪量 ${ }^{11)}$ の平均值, 1 月及び 2 月の福 井 $^{12)}$ ・厳原 ${ }^{13)}$ のそれぞれ平均気温, Sts. $3,4,5$ の平均表面水温, 平均水温と気温との差, 平均水 温と厳原の気温との差等を示す.これから降雪量 (里雪) と福井, 厳原の気温との相関が大きく, 気 温が低い時，積雪量が大きいことがみられる．宇 田 ${ }^{14)}$ は水温と気温の差が積雪量と 0.27 及び 0.35 の相関を認め, 対馬暖流の消長と裏日本の雪量と の関係を推しているが，われわれはこれは気温が 雪量に大きく影響し，水温は影響が少ないと考え る.すなわち, 水温または水温と気温の差は積雪 量とあまり相関がみられない.これをよりよく示 すため Fig. 12 は横軸に厳原の気温, 従軸に Sts. $3,4,5$ の平均表面水温と笽原の気温の差をとり, その時上述の平均積雪量を $1 \mathrm{~m}$ 以上と $40 \mathrm{~cm}$ 以 下及び $40 \sim 100 \mathrm{~cm}$ にわけて図示した。

これょり気温一水温差に関係なく, $1 \mathrm{~m}$ 以上の 積雪 (図中@で示す) は厳原の気温が $4.5^{\circ} \mathrm{C}$ 以下 であることが必要のようである。

蒸発量は $E=3.7\left(\bar{e}_{w}-\bar{e}_{a}\right) \bar{u}^{2)}$ なる式で与えられ る.ここに $\overline{\boldsymbol{e}}_{w}, \overline{\boldsymbol{e}}_{a}$ は海面及び空気の平均蒸気圧, $\bar{u}$ は平均風速であるから, $E$ は水温と気温の差に 比例する.一般に水温変動は夏季に大きく, 冬季に は小さいから $E$ はもっぱら気温に支配されること になる.すなわち水と熱の供給源たる海況の変動 は小さいのであるがそれを受け入れる大気の温度 が低い時，大雪になることを示している.

さて福井北西海域での蒸発量を見積ってみると

$$
E=\frac{Q_{s}-Q_{b}+Q_{v}+Q_{\theta}}{L(1+R)}
$$

なる式で与えられる2).

ここに $E:$ 蒸発量 


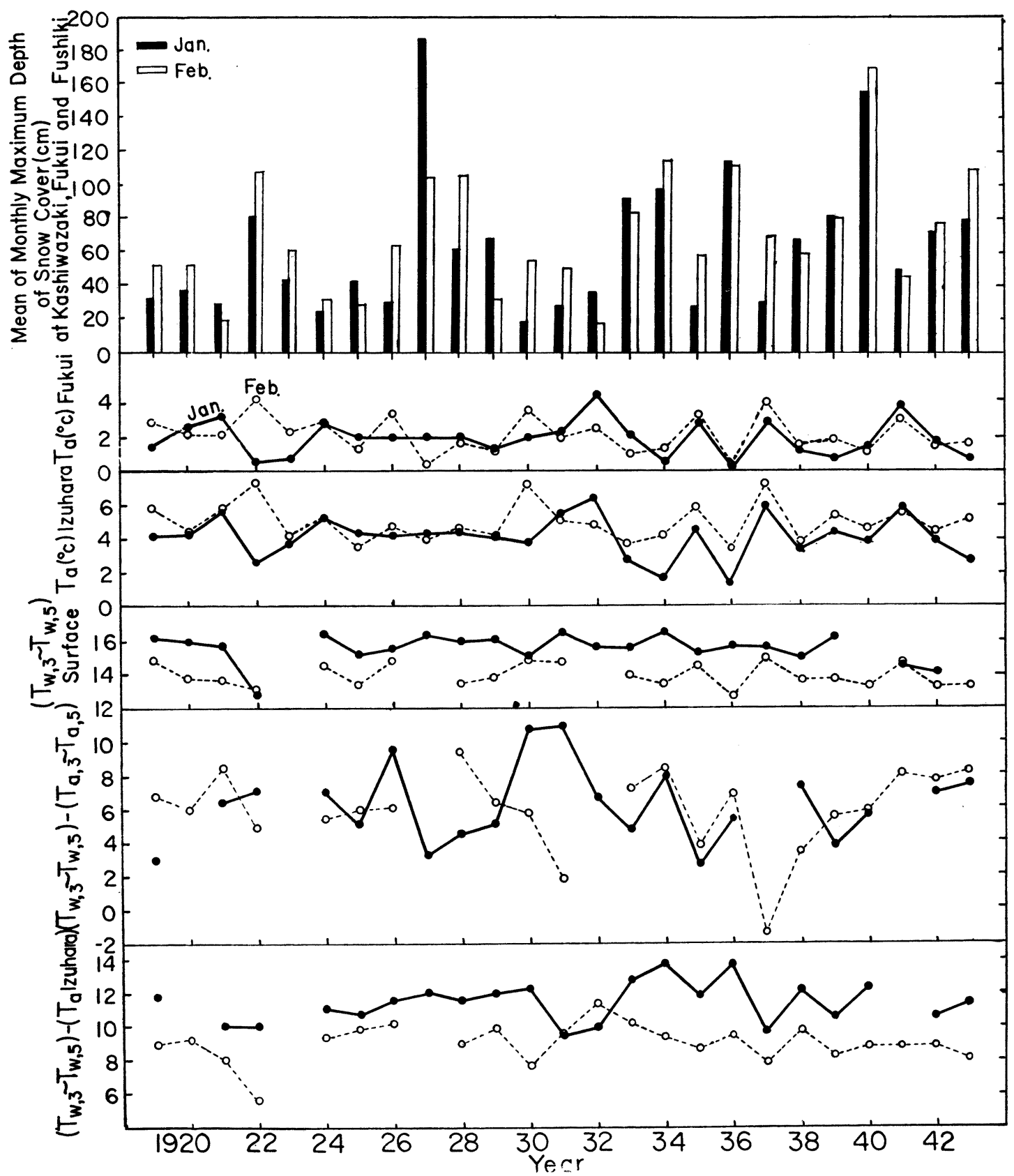

Fig. 11. Variations of depth of snow cover, air temperature, water temperature, and their differences. 
Table 5. Total incoming radiation $\left(Q_{s}\right)$, back radiation $\left(Q_{b}\right)$, advection of heat $\left(Q_{v}\right)$, local heat change $\left(Q_{\theta}\right)$ and evaporation $(E)$.

\begin{tabular}{|c|c|c|c|c|c|c|}
\hline & $Q_{s}$ & $\begin{array}{l}(\mathrm{g} \cdot \mathrm{c} \\
Q_{b}\end{array}$ & $\begin{array}{c}\left.\min ^{-1}\right) \\
Q_{v}\end{array}$ & $Q_{\theta}$ & $R$ & $\frac{\left(\mathrm{mm} \cdot \mathrm{day}^{-1}\right)}{E}$ \\
\hline Average year & 0.351 & 0.058 & 0.729 & -0.372 & 0.7 & 11.3 \\
\hline
\end{tabular}

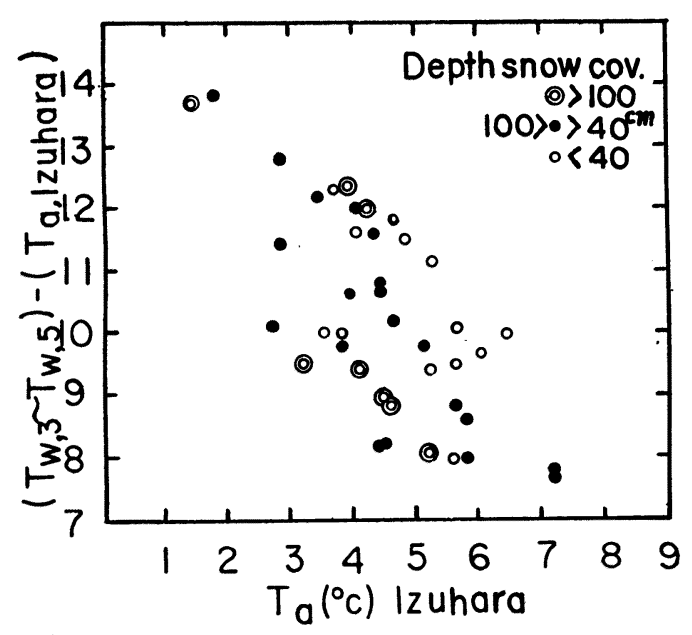

Fig. 12. Relationship between air temperature at Izuhara, temperature difference of water and air and depth of snow cover.
$Q_{s}$ ：太陽と天空からの放射の吸収熱量
$Q_{b}:$ 海表面からの逆放射量
$Q_{v}:$ 海流によって運ばれる熱量
$Q_{\theta}:$ 海水温を高める熱量
$L:$ 蒸発の潜熱
$R:$ Bowen ratio

である・

$$
\begin{aligned}
\text { ただ }, \quad Q_{v} & =C_{p} \rho \int_{0}^{100} u \frac{\partial \theta}{\partial x} d z \\
Q_{\theta} & =C_{p} \rho \int_{0}^{100} \frac{\partial \theta}{\partial t} d z
\end{aligned}
$$

で, ここに $C_{p}$ は定圧比熱, $\rho$ は密度, $\theta$ は水温, $u$ は $x$ 方向の流速で $100 \mathrm{~m}$ まで積分する.

福井北西海域の水温鉛直分布が $100 \mathrm{~m}$ の深さま でほとんど同一の温度であること，及び平年時 1 月は $12.6^{\circ} \mathrm{C}, 2$ 月は $11.0^{\circ} \mathrm{C}$ 及び対馬海峡 1 月 の平均值 $16.0^{\circ} \mathrm{C}$ を用いると

$$
\begin{aligned}
& \frac{\Delta \theta}{\Delta x}=\frac{16.0-12.6\left({ }^{\circ} \mathrm{C}\right)}{700(\mathrm{~km})}=4.86 \times 10^{-8}\left({ }^{\circ} \mathrm{C} \cdot \mathrm{cm}^{-1}\right) \\
& u=25 \mathrm{~cm} / \mathrm{sec} \\
& \frac{\Delta \theta}{\Delta t}=[12.6-11.0]\left({ }^{\circ} \mathrm{C}\right) / 1(\text { 月 }) \\
&=6.17 \times 10^{-7} \\
&\left({ }^{\circ} \mathrm{C} \cdot \mathrm{sec}^{-1}\right)
\end{aligned}
$$

となる。

これより Table 5 を得るが，藤田・本多 ${ }^{15} は 1$ 月の平年時蒸発量は $8 \mathrm{~mm} \cdot \mathrm{day}^{-1}$, 豪雪時の蒸発 量は平年時の $1.5 \sim 2$ 倍の $12 \sim 14 \mathrm{~mm} \cdot \mathrm{day}^{-1}$ で あると見積っている. われわれの平年時の值 $E=$ $11.3 \mathrm{~mm} \cdot \mathrm{day}^{-1}$ は彼等の豪雪時の值に近い.

この不一致は両者の算出の方式が異なるためで あろうか。

\section{5. 結 論}

過去 40 年に亘る東対馬水道の連続海洋観測値 を用い, 同水道の各月平均水温, 塩分図を求めた. また水温の変動から $2,7,8$ 年の有意の周期を求 めた。

水温と北陸豪雪の関係を調べたが，水温の変動 幅が小さいので,これはむしろ気温の高低に左右 され，たとえば厳原の 1,2 月の平均気温が 4.5 ${ }^{\circ} \mathrm{C}$ 以下の時に豪雪を見るようである。

MERIAC-I-F による周期分析について降籏常 雄氏，種々御助言をいただいた森安茂雄博士，藤 田敏夫氏に感謝する.

\section{文献}

1）福岡県福岡水産試験場 (1953)：東対馬水道海洋観 測資料一一自大正 2 年 9 月至昭和 27 年 2 月.

2) SVERDRUP, Harald U. Martin W. JOHNSON and Richard H. Fleming (1942): The Oceans. Prentice-Hall, New York.

3) NAN-NITI Tosio (1964): Oceanic turbulence. Oceanogr. Mag., 16 (1 2), 35-45. 
4）降籏常雄 (1959)：新しい自動データ処理機械 MERIAC-I-F について. 気象と統計， 10 (1), 23-31.

5）福岡二郎 (1965): 海況異常変動の実例について. 日本海洋学会誌, 21 (5), 221-223.

6）日高孝次・鈴木算 (1950)：対馬海流の永年変化に ついて. 日本海洋学会誌, 6 (1), 28-31.

7) FuKUOKA Jiro (1957): On the variation of oceanic conditions in the sea adjacent to Japan. Oceanogr. Mag., 9 (1), 95-106.

8）川合英夫 (1955)：東北海区に拾ける極前線とそ の変動について (第 1 報). 東北海区水産研究所研 究報告, 第 4 号.
9）畑中正吉（1952）：海況の変動に関する漁業生物 学的研究. 東北海区水産研究所研究報告, 創刊号.

10）福岡二郎 (1959)：海況の周期性について. 海と 空, 35 (1), 13-20.

11）気象庁 (1963): 積雪量累年気候表 (34 版).

12）福井地方気象台（1963）：福井県の気象.

13）長崎海洋気象台（1962）：長崎県の気象.

14）宇田道隆 (1936)：雪量と海水温度との関係. 天 気と気候，3(8)，349-350.

15）藤田敏夫・本多庸浩（1965）：冬期の日本海加 の蒸発量及び顕熱放出量の推定. 天気, 12 (6), 204-213. 